\title{
Correction to: The design and implementation of a longitudinal social medicine curriculum at the University of Vermont's Larner College of Medicine
}

Raghav K. Goyal ${ }^{\dagger}$, Christina A. Dawson ${ }^{\dagger}$, Samuel B. Epstein ${ }^{\dagger}$, Richard J. Brach, Sheridan M. Finnie, Karen M. Lounsbury, Timothy Lahey ${ }^{*}$ and Shaden T. Eldakar-Hein

Correction to: BMC Med Educ 21, 131 (2021)

https://doi.org/10.1186/s12909-021-02533-x

Following publication of the original article [1], the authors informed us that Fig. 1 has been labeled as "Before intervention" and "Before intervention" instead of "Before intervention" and "After intervention".

The original article has been corrected.

Published online: 10 March 2021

\section{Reference}

1. Goyal, et al. The design and implementation of a longitudinal social medicine curriculum at the University of Vermont's Larner College of Medicine. BMC Med Educ. 2021;21:131 https://doi.org/10.1186/s12909-02102533-x.

* Correspondence: Timothy.Lahey@med.UVM.edu

${ }^{\dagger}$ Raghav K. Goyal, Christina A. Dawson and Samuel B. Epstein contributed equally to this work.

University of Vermont's Larner College of Medicine, UVMMC, 111 Colchester,

Ave, Smith 2, Burlington, VT 05401, USA

C C The Author(s). 2021 Open Access This article is licensed under a Creative Commons Attribution 4.0 International License, which permits use, sharing, adaptation, distribution and reproduction in any medium or format, as long as you give appropriate credit to the original author(s) and the source, provide a link to the Creative Commons licence, and indicate if changes were made. The images or other third party material in this article are included in the article's Creative Commons licence, unless indicated otherwise in a credit line to the material. If material is not included in the article's Creative Commons licence and your intended use is not permitted by statutory regulation or exceeds the permitted use, you will need to obtain permission directly from the copyright holder. To view a copy of this licence, visit http://creativecommons.org/licenses/by/4.0/. The Creative Commons Public Domain Dedication waiver (http://creativecommons.org/publicdomain/zero/1.0/) applies to the data made available in this article, unless otherwise stated in a credit line to the data. 